\title{
MUNICIPAL ORDINANCES RELATING TO THE REMOVAL OF ICE AND SNOW FROM SIDE- WALKS.
}

What is the principle upon which an abutter is compelled by a municipal corporation to remove ice and snow from the sidewalk in front of his lot? Is it a simple exercise of the policc power, or is it on account of the special benefit that the abutter derives from the existence of the sidewalk?

In his work on Muncipal Corporations, Judge Dillon says: "The full conception of the true nature of a public street in a city, as respects the rights of the public on the one hand, and the rights of the adjoining owner on the other, has been slowly evolved from experience. It has only been at a recent period in our legal history that these two distinct rights have, separately and in their relations to each other, come to be understood and defined with precision." 2 Perhaps it is on this account that there exists some uncertainty as to these respective rights. In order to keep the discussion on the lines of general principles, I propose to consider the question only with reference to municipal corporations proper, leaving out the cases of quasi-corporations having governmental duties, such as counties and towns.

It seems that at common law there is no implied liability on the part of municipal corporations for injuries resulting from.. unsafe streets. But where the charter confers upon a municipal corporation ordinary powers over streets within its limits, the latter owes to the public the duty to keep the streets in a reasonably safe condition for use in the usual mode by travelers, and it is liable in a civil action for special injuries resulting from neglect to perform this duty. This is so, in the absence of a Statute expressly imposing the duty and declaring the liability, when $(a)$ the street is one which it is the duty of the corporation to keep in a safe condition; (b) which duty must appear to rest upon the municipal corporation as such, and not upon it as an agency of the State; $(c)$ and when the power to perform the duty, by authority to levy taxes or impose local assessments for the purpose, is conferred upon the municipality. ${ }^{2}$

1 Fourth edition, p. 777, Sec. 656 a.

2 Dillon Mun. Corp., Sec. ror7. 
It is of the essence of the street, says Judge Dillon, that it is public, and hence under the paramount control of the Legislature as the representative of the public. The authority of municipalities over streets they derive from the Legislature, from charter or Statute. The fundamental idea of a street is not only that it is public, but public for all purposes of free and unobstructed passage, which is its chief and primary, but by no means sole, use.

We may say, therefore, that the primary object for which the legislative control is delegated to municipal corporations to care for, supervise, and control streets, is to preserve for the public free passage, and all the powers granted to local authorities must be exercised with this primary object in view. To effect this, the corporate authority may control the laying of gas, water, and sewer pipes under the street; the placing of telegraph and telephone poles, and the laying of railroad tracks on the surface; may regulate the traffic on the streets by making ordinances respecting wagons, carts, drays, etc.; and may improve and grade the streets themselves.

The streets are for the use of all, and free to all, and it is for the interests of all that the foregoing powers of control are delegated to municipal corporations. But there is one class of the public which, in addition to the interest it has in the streets in common with the rest of the community, has a special interest therein. This class is composed of the owners of property abutting on the street, whom I designate, for convenience, as abutters. Whether the fee of the street be in the public or in the abutter himself subject to the public easement, the abutter has rights peculiar to himself, such as rights of access, light, and air, which must be protected. Judge Dillon sums up these rights as follows: Whether the fee of the street be in the abutter subject to the rights of the public, or whether it be in the public in trust for street uses proper, the abutter is entitled to the benefit of the street for all uses except street uses proper, subject to legislative and municipal regulations. Such rights are property or property rights in the abutter which can only be taken away by the Legislature on the condition of making compensation. If the abutter owns the fee, his rights may be said to be legal in their nature. If he does not own the fee, these rights are in the nature of equitable easements in fee."

From this short review of the subject, it is fair to conclude that the position of an abutter with respect to the street to.

Sec. 683.

Sec. 723 c. 
which his lot is adjacent is the same as that of the general public, with the exception that he has certain property rights appertaining to him in respect to his abutting realty, and he is, for the same reason, subject to certain liabilities regarding the streets.

These liabilities seem to me to fall into two classes, viz., (a) those which attach in consequence of some special benefit accruing to him through the position of his property on the street, when some substantial improvement is carried out on the street; and (b) those which attach, on the maxim sic utere tuo ut alienum non ladas, when, by his wrongful act or omission with respect to his abutting property, some special injury results to others.

The first class, which does not require extended discussion here, includes special assessments made upon abutting owners to meet the cost of street improvements. It is sufficient to say that these assessments must not exceed substantially the value of the special benefit accruing, any further burden being a taking of private property without compensation, $i . e_{\text {. }}$, due process of law. ${ }^{8}$

The second class includes any nuisance, such as permanent obstruction of the public highway, or any act or omission rendering the highway unsafe or inconvenient for public use.

It is conceived that these two classes comprise all the liabilities of abutters that are peculiar to them as such, and that in all other respects the abutter stands, in his relation to the public streets, in the same position as the rest of the community. For the general management and care of the streets he is no more responsible than are other citizens. His duties are limited to paying for special benefits and abstaining from wrongful use of his property.

This brings me to the subject of this paper. Upon what principle may a municipal corporation, endowed by its charter with the care, regulation, and control of the streets within its jurisdiction, compel, by ordinance, abutting owners to remove ice and snow from the sidewalks adjacent to their lots?

The purpose of such an ordinance is, of course, to effect the removal of inconvenient and sometimes dangerous obstructions as speedily as possible. But why should this public duty be imposed upon abutters?

- The question was raised in Massachusetts many years ago, and the validity of the ordinance was upheld by the Supreme Court of that State in an opinion by Shaw, C. J.'

${ }^{5}$ Norwood v. Baker, S. C. Rep. Oct., I898.

${ }^{6}$ Goddard, Petitioner, I6 Pick. 504; 28 Am., Dec. 259. 
Passing over some technical points of no importance here, the chief objection raised to the ordinance was that it imposed a tax or duty upon the citizens which was unconstitutional because it was partial and unequal, and in contravention of that fundamental maxim of our social system that all burdens and taxes laid on the people for the public good shall be equal.

The Chief Justice disposes of this objection as follows: The ordinance does not levy a tax, but rather imposes a duty upon a numerous class, a duty which falls equally upon every member of that class. It is a police regulation, highly salutary to the citizens of a populous and closely built city, and it is imposed upon the class in question because it can most conveniently and promptly perform it. The opinion continues: "Although the sidewalk is part of the public street and the public have an easement in it, yet the adjacent occupant is often the owner of the fee, and generally has some peculiar interest in it and benefit from it distinct from that which he enjoys in common with the rest of the community. *** The answer to the objection of partiality and inequality is that the duty required is a duty upon the person in respect to the property which he holds, occupies and enjoys under the protection and benefit of the laws, that it operates upon each and all in their turns, as they become owners and occupiers of such estates, and it ceases to be required of them when they cease to be holders and occupiers. In this respect, it is like a land tax or house tax."

This opinion sustains the validity of the ordinance upon the ground that for the general good the police power may impose upon a certain class of citizens the burden of removing a public nuisance in which all classes of the community have an in terest, and which the peculiar class selected had not in any way caused.

It is true that the court justifies the imposition partly on the ground of the special interest the abutter has in gaining access to his house, cellar door, steps, etc. It would seem that an ordinance would hardly be necessary to induce the owners of houses to remove any inconvenience resulting to themselves of the nature described in the opinion. Moreover, although special benefit to a class may justify the imposition upon that class of special taxation, it is a novel reason for the application of the police power. If an ordinance of this nature is to be justified as an exercise of the police power, it must be on account of the public good and not the private benefit. 
In Illinois a different view is taken. The Supreme Court of that State considers that the abutter has no other interest in the street in front of his property than any other citizen of the munieipality; and that the same is true of the sidewalk. The sidewalk is as much under the control of the municipality as is the street itself. The owner of the adjacent lot is under no more obligation to keep the sidewalk free from obstructions than he is the street in front of his premises. "It will be conceded that the citizen is not bound to keep the street in front of his premises free from snow or anything else that might impede travel, then upon what principle can he be fined for not removing snow or other obstruction from the sidewalk in which he has no interest other than what he has in common with all other persons resident in the city? It is certainly not upon the principle under which assessments are made against the owner for building sidewalks in front of his property. The cases are not analogous. Such assessments are maintained on the ground that the sidewalk enhances the value of the property, and to the extent of the special benefit conferred they are held to be valid. *** The sidewalk $* * *$ is as much a public highway free to the use of all as the street itself, and upon principle it follows the citizen cannot be laid under obligation under our laws to keep it free from obstructions in front of his property at his own expense, any more than the street itself, either by the exercise of the police power, or by fines and penalties imposed by ordinance, or by direct legislative action."

In a later case in the same State, ${ }^{8}$ an attempt was made to induce the court to overrule the last mentioned decision, on the ground that the ordinance was a proper police regulation. But the attempt failed, the court saying: "Even the police power, comprehensive as it is, has some limitations. It cannot be held to sanction the taking of private property for public use without making just compensation therefor, however essential this might be for the time to the public health, safety, etc. And upon like principle, a purely public burden cannot be laid upon a private individual except as authorized in cases to exercise the right of eminent domain, or by virtue of proper proceedings to enforce special assessments or special taxation." The opinion then argues that ice and snow on a sidewalk may be declared a nuisance, but if so, it is a public nuisance, and one occasioned by natural causes and not by the action of the abut-

'Gridley v. City of Bloomington, 88 IIl. 554.

${ }^{8}$ City of Chicago v. O'Brien, III Ill. 532. 
ter. The latter may have no more actual control of the street than if his property were miles away; still he is held responsible for a result he could not control, and to the production of which he did not even theoretically contribute. The court concludes: "The gist of the whole argument is merely that it is convenient to hold him responsible. It is not perceived why it would not be equally convenient to hold him responsible for the entire police government of so much of the street." The views of courts as to the extent of the police power have changed in recent years. The last mentioned decision was rendered in I884, and it proceeds largely upon the assumption that the police power cannot be exercised in the laying of a public bur-, den upon a private person without compensation to him. But in I890, the Court of Appeal of New York had occasion ${ }^{\circ}$ to consider the validity of a similar ordinance. In upholding it, the court says: "Muncipal corporations have exercised this (police) power, eo nomine, for time out of mind, by making regulations to preserve order, to promote freedom of communication, and to facilitate the transaction of business in crowded communities. Compensation has never been a condition of its exercise even when attended with inconvenience or pecuniary loss, as each member of a community is presumed to be benefited by that which promotes the general welfare."

It will be noticed that the court holds that compensation is not a necessary element in the exercise of the police power. And while this doctrine would seem to be correct in cases of nuisances within the control of the party placeci under the burden, it savors of hard justice to make him bear the consequences of a state of things for which he is in no way responsible.

It is worthy of notice that the opinion in this New York case refers to Gridley v. City of Bloomington (supra) as follows: "The argument upon which the opinion in that case rests is that as the fee of the street was in the corporation and the sidewalk was a part of the,street, the lot owner had no more interest in the sidewalk in front of his premises than any other citizen of the municipality, because it was set apart for the exclusive use of persons traveling on foot, and was as much under the control of the municipal government as the street itself."

This seems to be a somewhat incorrect statement of the opinion in the Illinois case referred to. The exact words used

- Village of Carthage v. Frederick, I22 N. Y. 269. 
were: "The public had an easement over the street in front of the lot occupied and owned by defendant, and it makes no difference, so far as this decision is concerned, whether the fee of the street passed by the plat and dedication to the corporation, or whether it remained in the original proprietor." It cannot, therefore, be said that the opinion rests on the fact that the fee of the street was in the corporation.

I thirik it is clear that the only ground on which the ordinance in question can be supported is that of the police power. Is the police power properly available in this case ? The principle on which it seems to be admitted in the case under consideration is that it is for the general convenience. No one who has studied the matter can fail to be struck with the great development of the ideas upon the extent of the police power in late years. Up to a generation ago the police power of the State, though theoretically extensive, was practically confined to the prevention of any acts or the punishment of any omississions of a private individual which would result in injury to the health, morals, or safety of the general public. This of course implies that the acts or omissions should be such as are under the control of the party. But it is universally recognized that the duty of keeping the streets in good condition rests upon the public authority, and even when the validity of the ordinance in question is sustained by the courts, it is held almost unanimously that the public authority is not thereby released from any liability for injury to a third party caused by a failure on the part of the abutter to obey the ordinance. ${ }^{10}$

In City of Rochester v. Campbell, Ruger, Ch. J., in upholding this view, says: "Any other conclusion than that reached by us would, we think, be most unfortunate, as it would tend to relax the vigilance of municipal corporations in the performance of their duties in respect to the repair of streets and highways, and impose that duty upon those who might be utterly unable to discharge it. It would tend directly to demoralize the public service and lead to disorder, decay and impassibility of the public highways."

And in City of Hartford v. Talcott, Pardee, J., says: "The individual owes no duty to the public in reference to the way except to remove therefrom all property of his own which obstructs it, and to refrain from doing or placing anything

${ }^{10}$ City of Rochester v. Campbell, 123 N. Y. 405; Monre v. Gadsden, 93 N. Y. 12; Kirby v. Boylston, I4 Gray 249; City of Hartford v. Talcott, 48 Conn. 526; Flynn vs. Canton, 40 Md. 312; Taylor v. R. R., 7 N. W. Rep. 728. 
thereon dangerous to the traveler. So far as defects in it result wholly from the operation of nature, the proprietor at whose front they exist is without responsibility for them. Therefore, where ice has accumulated upon the sidewalk to a dangerous extent, it is the duty of the municipality to remove or cover it within a reasonable time after its formation." The court then cites the charter authorizing the ordinance, and continues: "The utmost reach of it is only to authorize the enactment of an ordinance requiring each proprietor upon the way to assist the city in restoring the walk to a condition of safety, with a fixed and reasonable penalty for disobedience."

In Taylor v. Railroad, a Statute provided that the negligent abutter should be liable to the city for any damages recovered against it through his negligence. Judge Cooley, in deciding that an action would not lie against an abutter by the injured party for injuries resulting from failure to remove ice and snow from the sidewalk, comments upon this Statute as follows: "Exactly what force is to be given to the provision of the Statute that the lot owner shall be liable to the city for all damages which the city may be compelled to pay for his default, we need not consider in this suit."

Thus it will be seen that, while it is generally held that a municipal corporation may delegate to the abutter the duty of clearing ice and snow from the sidewalk, it cannot discharge itself from liability for any injury resulting from a failure to perform the delegated duty.

It seems difficult to avoid the conclusion that where the duty is so plainly and confessedly a public one, its imposition upon a certain class of citizens, however large, is the imposition of an unequal burden. The authors of "Municipal Police Ordinances" "refer to the matter in these words: "While it is clear that municipal corporations can prevent private individuals from obstructing travel on the streets by their own acts, it is somewhat doubtful whether they have power to compel adjoining owners to keep the sidewalks clear from snow so as to be passable." After referring to the Illinois decisions, they continue: "Though this view is in one sense correct, still considerations of public benefit should overbalance any slight inconvenience to the individual. **.* Adjoining owners are so situated as to be able to clear the walks in a short time, and though a slight inequality of burden may fall upon the citizens thereby, such regulations ought to be sustained as proper and reasonable police measures."

\footnotetext{
"Horr and Bemis, Mun. Pol. Ord., p. 228, Sec. 235.
} 
Our conclusion must be, therefore, that these ordinances, though avowedly imposing an unequal burden, are sustained as a valid exercise of the police power on account of the general convenience. :

Thus the question narrows down to this: What is the extent of the police power? On this point opinions of the present day are by no means in harmony. Subject to constitutional provisions, which are themselves capable of different interpretations, the police power of a State is practically that which the citizens of the State permit it to be.

As the dominant ideas of the rights of the public as against individual rights or convenience change, so will the police power change. An illustration of this may be found in the legislation relating to intoxicating liquors. About forty years ago it was decided in New York, in the case of Wynehamer v. People, that Statutes prohibiting the manufacture and sale of intoxicants were unconstitutional so far as they related to liquors in existence at the time of the passage of the Statutes, this being a deprivation of property without due process of law. In 1887 , a decision of the Supreme Court of the United States ${ }^{13}$ affirmed the validity of a Kansas Statute under which the owner of a brewery, which was in existence before the manufacture and sale of intoxicating liquors were prohibited, was compelled to suffer the loss of all his stock in trade without compensation. His right to compensation was denied on the ground that his business had become a nuisance, and as such could be abated. A generation intervened between these decisions on the scope of the police power, and public opinion had in the meantime sanctioned an exercise of this power which would formerly have been regarded as pure confiscation.

I cite these cases simply as illustrations of the flexible character of the police power. It is not, therefore, surprising to find that opposite views of the validity of its exercise in the question under consideration should be held in different jurisdictions. But on looking at the decisions and the principles on which they rest, it is difficult to come to any other conclusion than that of the Illinois court, in Chicago v. O'Brien, already cited, viz.: "The gist of the whole argument is merely that it is convenient to hold him responsible. It is not perceived why it would not be equally convenient to hold him responsible for the entire police government of so much of the street."

William Frederic Foster.

"Mugler v. Kansas, I23 U. S. 623. 